\title{
Oxidative Coupling of Methane in Solid Oxide Fuel Cell Tubular Membrane Reactor with High Ethylene Yield
}

\author{
Kefeng Liu, ${ }^{a}$ Jing Zhao, ${ }^{\mathrm{b}}$ Di Zhu, ${ }^{\mathrm{b}}$ Fei Meng, ${ }^{\mathrm{b}}$ Fanhua Kong, ${ }^{a}$ and Yongchun Tang ${ }^{\mathrm{b}^{*}}$
}

\begin{abstract}
A $\mathrm{Mn}$-Ce- $\mathrm{Na}_{2} \mathrm{WO}_{4} / \mathrm{SiO}_{2}$ catalyst integrated solid oxide fuel cell tubular membrane reactor design is developed for oxidative coupling of methane (OCM). The OCM reaction carried out using the tubular membrane reactor establishes both superb hydrocarbon selectivity and outstanding ethylene-to-ethane ratio over the conventional fixed bed OCM or the button cell reactor. A remarkable performance of $60.7 \%$ methane conversion with $41.6 \% \mathrm{C} 2+$ selectivity, 5.8 ethylene-to-ethane ratio and $19.4 \%$ ethylene yield is achieved using the tubular membrane reactor and the $\mathrm{Mn}-\mathrm{Ce}-\mathrm{Na}_{2} \mathrm{WO}_{4} / \mathrm{SiO}_{2}$ catalyst, demonstrating considerable advantages over conventional OCM.
\end{abstract}

\section{Keywords}

OCM, SOFC, methane, ethylene, membrane reactor, $\mathrm{Mn}-\mathrm{Ce}-\mathrm{Na}_{2} \mathrm{WO}_{4}$

\section{Introduction}

The increasing demands in energy along with the expected long-term decline in petroleum reserves require alternative hydrocarbon feedstocks for the production of important industrial chemical intermediates such as ethylene. Methane $\left(\mathrm{CH}_{4}\right)$, the major component of natural gas, is a promising starting material because it has the desirable carbon-hydrogen ratio as well as abundant reserves.[1] The efficient conversion of methane, which otherwise is primarily used as fuel for power generation, to value-added chemicals is highly demanded. Conventionally, multiple steps are required to convert methane into value-added chemicals, where methane is first reformed to synthesis gas ( $\mathrm{CO}$ and $\mathrm{H}_{2}$ ), followed by the Fischer-Tropsch process to produce alkenes or the catalytic conversion to produce methanol and the subsequent methanol-to-olefin (MTO) processes. However, the capital and maintenance costs are relatively high in these rather complicated processes. A direct route for the conversion of methane into value-added chemicals is highly demanded.[2,3]

Oxidative coupling of methane (OCM) has been studied for decades[4-13] and is recently being commercialized by Siluria Technologies. In a typical OCM process, methane and pure oxygen are co-fed 
through a metal oxide catalyst bed and transformed to ethane, ethylene, and carbon oxides at 500$800^{\circ} \mathrm{C}$. The main reaction proceeds as:

$$
2 \mathrm{CH}_{4}(\mathrm{~g})+\mathrm{O}_{2}(\mathrm{~g}) \rightarrow \mathrm{C}_{2} \mathrm{H}_{4}(\mathrm{~g})+2 \mathrm{H}_{2} \mathrm{O}(\mathrm{g})
$$

There are several shortcomings of the conventional OCM process, namely, the requirement of airseparation units for the feed of pure oxygen, the unsatisfying yield of ethylene due to the deep oxidation of methane, and the potential explosion hazard from direct mixing of hydrocarbon with pure oxygen.[14] In this communication, we present a solid oxide fuel cell (SOFC) facilitated OCM membrane reactor that simultaneously addresses these problems associated with conventional OCM.

The catalytic membrane reactors have been intensively studied in the last two decades to improve yields of olefin in selective oxidation reactions. A number of comprehensive reviews on this subject are available.[15-21] It is generally accepted that the use of membrane reactors in selective oxidation reactions can benefit olefin selectivity by the distributed feeding of oxygen to suppress deep oxidation. However, these oxygen permeable membrane reactors suffer from the inherent low oxygen flux, resulting in low methane conversion despite of the high selectivity reported and cited in many studies.[22,23] The SOFC membrane reactor introduced here inherits the advantages of conventional catalytic membrane reactor while providing a simple way of tuning the oxygen flux by adjusting the working current of the cell.[24] For instance, Morejudo et al. recently demonstrated a successful integration of a co-ionic conducting SOFC device with the methane dehydroaromatization(MDA) reaction to improve the aromatics selectivity as well as the stability of catalysts.[3] In our study, several OCM catalysts were synthesized and integrated with SOFC, with the purpose to establish advanced SOFC membrane reactors and overcome the problems of traditional OCM process. Through a careful evaluation and optimization of the OCM catalysts, as well as a significant improvement on the SOFC reactor design, we have achieved a very promising catalyst-integrated SOFC tubular membrane reactor demonstrating superior performance, including higher hydrocarbon selectivity and better ethylene-toethane ratio, to the conventional OCM process. Our novel process also enables a safer operation with less expensive process cost, making OCM a practical route for producing ethylene from the abundant methane reserves.

\section{Experimental}

\subsection{Catalyst synthesis}

All OCM catalysts investigated in this study were synthesized using chemicals from Sigma Aldrich,

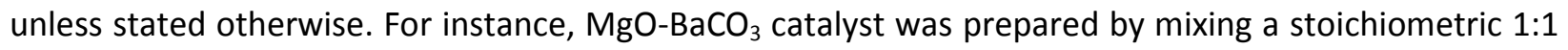
amount of magnesium nitrate and barium oxalate in water followed by drying at $80{ }^{\circ} \mathrm{C}$ and calcining at $800{ }^{\circ} \mathrm{C}$ for 4 h.[25] LaAlMgO catalyst was obtained in a similar manner by dissolving the desired amount of lanthanum nitrate, aluminum nitrate and magnesium nitrate in citric acid and evaporating stepwise at $80^{\circ} \mathrm{C}$ and $100^{\circ} \mathrm{C}$. A final calcination at $800^{\circ} \mathrm{C}$ for $5 \mathrm{~h}$ was applied to convert the mixture to the desired composition.[26] Supported $\mathrm{Mn}-\mathrm{Ce}-\mathrm{Na}_{2} \mathrm{WO}_{4}$ catalysts were synthesized following the wet impregnation method.[27-29] The desired support was first impregnated with aqueous solutions of $\mathrm{Mn}\left(\mathrm{NO}_{3}\right)_{2}$, $\mathrm{Ce}\left(\mathrm{NO}_{3}\right)_{3}$ and $\mathrm{Na}_{2} \mathrm{WO}_{4}$ at $80{ }^{\circ} \mathrm{C}$ and evaporated, followed by calcination at $850^{\circ} \mathrm{C}$ for $6 \mathrm{~h}$. Various supports investigated were $\mathrm{La}_{0.75} \mathrm{Sr}_{0.25} \mathrm{Cr}_{0.5} \mathrm{Mn}_{0.5} \mathrm{O}_{2.88} \quad$ (LSCrM),[30] $\mathrm{Gd}_{0.2} \mathrm{Ce}_{0.8} \mathrm{O}_{1.9} \quad$ (GDC, 
Fuelcellmaterials.com, SKU: 112102), $\left(\mathrm{Y}_{2} \mathrm{O}_{3}\right)_{0.08}\left(\mathrm{ZrO}_{2}\right) 0_{.92}(\mathrm{YSZ}$, Fuellcellmaterials.com, SKU: 312005$), \mathrm{SiO}_{2}$ particles (0.5-10 $\mu \mathrm{m}$, Sigma-Aldrich, S5631) and $\mathrm{SiO}_{2}$ gel (pore size $15 \mathrm{~nm}$, Sigma-Aldrich, 236845), with the corresponding yielded catalysts labelled as $\mathrm{Mn}-\mathrm{Ce}-\mathrm{Na}_{2} \mathrm{WO}_{4} / \mathrm{LSCrM}, \mathrm{Mn}-\mathrm{Ce}-\mathrm{Na}_{2} \mathrm{WO}_{4} / \mathrm{GDC}, \mathrm{Mn}-\mathrm{Ce}-$ $\mathrm{Na}_{2} \mathrm{WO}_{4} / \mathrm{YSZ}, \mathrm{Mn}-\mathrm{Ce}-\mathrm{Na}_{2} \mathrm{WO}_{4} / \mathrm{SiO}_{2} \mathrm{NPs}$ and $\mathrm{Mn}-\mathrm{Ce}-\mathrm{Na}_{2} \mathrm{WO}_{4} / \mathrm{SiO}_{2}$ gel, respectively.

\subsection{Cell integration}

In an effort to integrate the OCM catalyst with the button/tubular cells, the catalyst slurry, made by blending crashed OCM catalyst powders with colloidal gold paste, was coated on the anode side of the

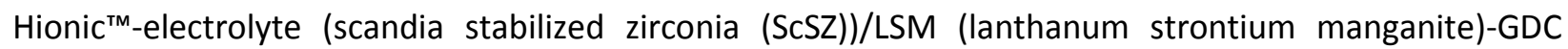
(gadolinium doped ceria)/LSM cathode multilayer cell structure (Fuelcellmaterials.com, single electrode cell) and calcined at $1100^{\circ} \mathrm{C}$ for $2 \mathrm{~h}$ (Fig. 1 inset). Gold wire and gold paste were used to complete the electrical contact, and high temperature ceramic sealing paste was used to seal customized cells on the alumina (99.8\%) support tube. In the button cell design, button cells with a diameter of $20 \mathrm{~mm}$ were mounted on one end of the support tube with the OCM anode facing inward. Additional OCM catalysts of the same kind were added in order to deplete the open space between cell and the lower end of the inner tube (methane inlet), as illustrated in Fig. 1 top. In the tubular geometry design, four rectangular cells of $40 \mathrm{~mm} \times 20 \mathrm{~mm}$ were mounted onto a $25.4 \pm 1 \mathrm{~mm}$ OD alumina (99.8\%) support tube with four customized rectangular matching open windows of $42 \mathrm{~mm} \times 21 \mathrm{~mm}$ evenly distributed around the tube. The resulted tube after cell mounting is in principle identical to a tubular SOFC (Fig. 1 bottom), with the inner tube surface composed of the OCM-active anode and the outer tube surface of the LSM cathode. Similarly, additional OCM catalysts were packed into the tubular reaction chamber to deplete the open space in the high-temperature cell regionto ensure sufficient contact between methane gas, oxygen source and the catalysts.

\subsection{Sample characterization}

Powder X-ray Diffraction (XRD) and Scanning Electron Microscopy (SEM) were conducted on the asobtained OCM catalysts to confirm the desired structure and morphology. Inductively coupled plasma mass spectrometry (ICP-MS) was used to determine the catalyst loading. XRD patterns were recorded on a Bruker D8 powder X-ray diffractometer equipped with $\mathrm{Cu} \mathrm{K}_{\alpha}$ as the X-ray source. All SEM images of the OCM catalysts as well as the cross-section micrographs of the cell structure were obtained on a Tescan Mira 3 high resolution scanning electron microscope. An Agilent 7700 spectrometer was used to collect the ICP-MS data.

\subsection{Catalytic activity test}

Fig. 1 pictures the schematic representation of the two different membrane reactor geometries adopted in our study. An easy-to-fabricate button cell design (Fig. 1 top) is used to screen for the SOFCcompatible best-performing catalyst from a comprehensive database of existing OCM catalysts, [31] and a tubular membrane reactor (Fig. 1 bottom) is designed to evaluate the synergistic effect between OCM and SOFC, utilizing the best OCM catalyst identified. $4 \mathrm{~g}$ of OCM catalysts were charged into the button cell reactor $6 \mathrm{~g}$ for the tubular reactor. In both scenarios, catalytic testing was conducted by feeding diluted methane gas $\left(\mathrm{P}_{\mathrm{CH} 4}=9.2 \mathrm{kPa}\right)$ to the inner anode chamber and air directly to the outer cathode 
environment. The mixture exiting the anode chamber was analyzed by Agilent 7890 , equipped with a natural gas analyzer. During operation, the SOFC unit functions as an internal oxygen pump to selectively transfer oxygen from the air cathode to the anode in the form of oxygen anion, with the amount of oxygen anion transferred per unit time being conveniently tuned by the cell current. As a result, no direct co-feed of methane and pure oxygen is required, featuring reduced operation cost and improved safety.

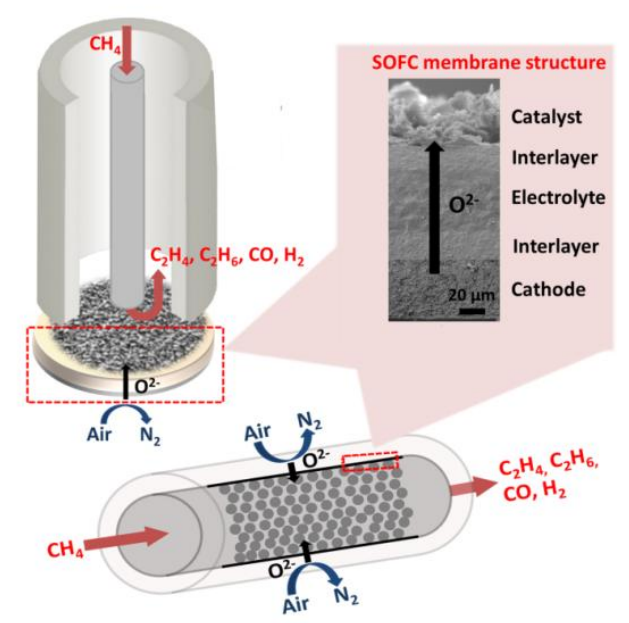

Fig. 1. Schematic diagrams demonstrating the SOFC-OCM button cell reactor with $4 \mathrm{~g}$ catalyst loading (top) and the tubular membrane reactor with $6 \mathrm{~g}$ catalyst loading (bottom) used in this study. SEM cross-section image of the multilayer SOFC membrane assembly is illustrated in insert.

\section{Results and discussions}

\subsection{Screening of Catalysts}

All OCM catalysts were synthesized following protocols reported in literatures. We firstly evaluated their performance using the button-cell reactor depicted in Fig. 1 top. All tests were conducted at comparable conditions of $800^{\circ} \mathrm{C}, 22 \mathrm{ml} / \mathrm{min}$ diluted methane gas flow, 0.37 A cell working current, $1 \mathrm{~cm}^{2}$ exposed cell area and the same $4 \mathrm{~g}$ catalyst loading, with the corresponding $\mathrm{CH}_{4}$-to- $\mathrm{O}^{2-}$ molar ratio of 1.9:1. Figure 2 summarizes the results of all catalysts screened in this work. In all experiments, carbon oxides and water are the only detected side products, with no coke deposition. In absence of a proper OCM catalyst, only $8.3 \%$ methane is converted at a selectivity of $22.6 \%$ towards ethane and ethylene. With a good catalyst, a complete utilization of all delivered oxygen can be achieved with good methane conversion and hydrocarbon selectivity. Particularly, we have identified the porous $\mathrm{SiO}_{2}$ gel supported $\mathrm{Mn}-\mathrm{Ce}-\mathrm{Na}_{2} \mathrm{WO}_{4}$ catalyst to be the best one with a performance of $29.5 \%$ methane conversion and $64.6 \%$ total hydrocarbon selectivity, which is in good agreement with literature reports on fixed-bed OCM using silica-supported $\mathrm{Mn}-\mathrm{Ce}-\mathrm{Na}_{2} \mathrm{WO}_{4}$.[27] 
Fig. 2. Catalytic performance, namely product selectivity and methane conversion, for a variety of OCM catalysts evaluated in this study, using the SOFC-OCM button cell design in Fig. 1 top.

XRD, SEM, and ICP-MS were used to characterize the composition, structure, and the morphology of as-prepared fresh $\mathrm{Mn}-\mathrm{Ce}-\mathrm{Na}_{2} \mathrm{WO}_{4} / \mathrm{SiO}_{2}$ catalyst, as shown in Fig. S1 in the supporting information. All of the peaks in the XRD diffractogram (Figure S1A) can be unequivocally indexed to four crystalline phase in the catalyst, namely crisbalite $\mathrm{SiO}_{2}, \mathrm{Na}_{2} \mathrm{WO}_{4}, \mathrm{MnO}_{2}$, and $\mathrm{CeO}_{2}$, which is in good agreement with previous reports.[27,32]. SEM image (Figure S1B) shows that the metal oxides are loaded on the surface of $\mathrm{SiO}_{2}$ particles. The loading amount is $2.2 \% \mathrm{Mn}-3.2 \% \mathrm{Ce}-4.9 \% \mathrm{Na}_{2} \mathrm{WO}_{4}$ on the $\mathrm{SiO}_{2}$ particles which is shown in the supporting Table S1.

In addition, the inset of Fig. 1 presents the cross-sectional SEM micrograph for a typical SOFC structure. The electrolyte, free of cracks and pinholes, is $50 \mu \mathrm{m}$ in thickness, whereas the porous cathode of lanthanum strontium manganite (LSM) and the customized anode of OCM catalyst-Au composite are approximately $60 \mu \mathrm{m}$ each. Anode interlayer composed of gadolinium-doped ceria (GDC) and scandium-stabilized zirconia (SSZ), and cathode interlayer of GDC and LSM, are present with a thickness of $20 \mu \mathrm{m}$ each. The complete cell ranges between $190 \mu \mathrm{m}$ and $230 \mu \mathrm{m}$ in total, providing good mechanical strength and no gas permeability.

\subsection{Current-tuned catalytic performance}

The dependence of catalytic response on cell working current was further investigated using the top performing $\mathrm{Mn}-\mathrm{Ce}-\mathrm{Na}_{2} \mathrm{WO}_{4} / \mathrm{SiO}_{2}$ gel catalyst in button cell reactor. Experiments were conducted at $800^{\circ} \mathrm{C}$ with diluted methane gas flow of $22 \mathrm{ml} / \mathrm{min}$ and $1 \mathrm{~cm}^{2}$ exposed cell area. This particular cell has an open circuit voltage of $0.670 \mathrm{~V}$ with a short circuit current of $0.17 \mathrm{~A}$. Instant response of catalytic activity is observed when cell current is altered hourly, with larger current leading to more transported oxygen and higher methane conversion, enabling a precise tuning of the catalytic performance. Notably, 
methane conversion of $50.7 \%$ with $44.0 \%$ C2+ selectivity and methane conversion of $59.4 \%$ with $35.8 \%$ $\mathrm{C} 2+$ selectivity are achieved, representative of the state of the art for OCM catalysts.[27,33,34] No decay in activity is noticed within the hourly window at each current, indicating a stable performance consistent with its coke-free characteristic. In addition, a co-feed of $\mathrm{CH}_{4}$ and pure oxygen $\left(\mathrm{CH}_{4}: \mathrm{O}_{2}=3: 1\right)$ experiment, equivalent to the conventional fixed bed test, was conducted at zero current (open circuit) with other parameters being identical. The amount of co-fed oxygen gas chosen is equal to the amount of oxygen source delivered by the SOFC button cell at a current of $0.47 \mathrm{~A}$. Similarly, $36.8 \%$ conversion and $57.4 \% \mathrm{C} 2+$ selectivity are measured, similar to the results in Fig. 3 at I $=0.47 \mathrm{~A}$, suggesting that in the button cell reactor, the oxygen source provided by SOFC functions in the same manner as the oxygen gas being co-fed in a typical fixed bed reactor. Table 1 summarizes our results as well as results from literature reports for better comparison.

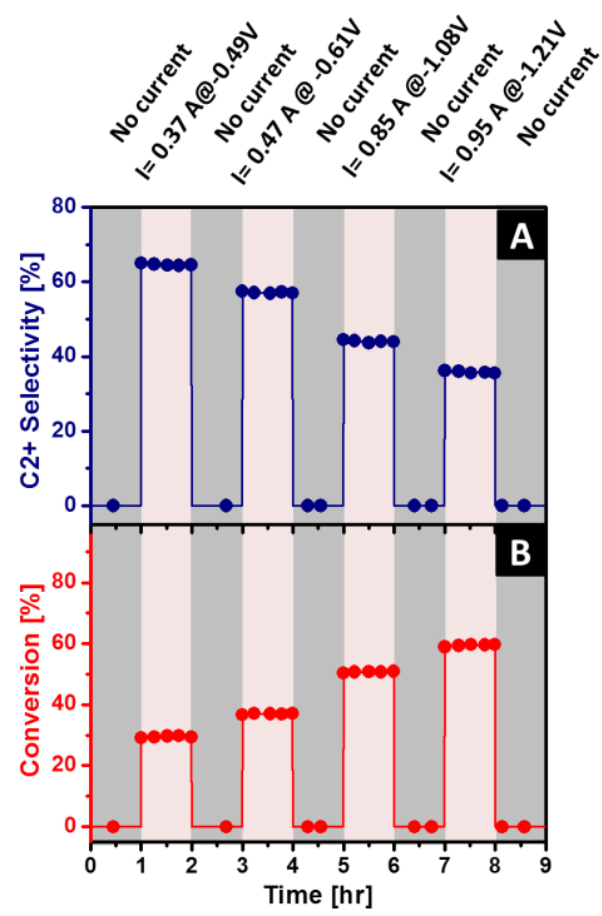

Fig. 3. $\mathrm{C} 2+$ selectivity (A) and methane conversion (B) as a function of reaction time and cell current. Catalyst: $\mathrm{Mn}$ $\mathrm{Ce}-\mathrm{Na}_{2} \mathrm{WO}_{4} / \mathrm{SiO}_{2}$ gel.

Table 1 Comparison of different reactor configuration

\begin{tabular}{c|ccccc}
\hline & Conversion & $\mathrm{C}_{2+}$ selectivity & $\mathrm{C}+\mathrm{S} \%$ & $\begin{array}{c}\text { Ethylene: } \\
\text { Ethane }\end{array}$ & Ethylene yield \\
\hline Fixed bed reactor & $36.8 \%$ & $57.4 \%$ & $94.2 \%$ & 1.7 & $12.6 \%$ \\
Button cell SOFC & $37.0 \%$ & $57.1 \%$ & $94.1 \%$ & 1.7 & $12.5 \%$ \\
Button cell SOFC & $59.4 \%$ & $35.8 \%$ & $95.2 \%$ & 2.3 & $14.1 \%$ \\
Tubular SOFC & $34.8 \%$ & $59.1 \%$ & $93.9 \%$ & 3.7 & $15.3 \%$
\end{tabular}




\subsection{Impact of reactor design}

With a good understanding of the catalytic performance at a full spectrum of working current for the $\mathrm{Mn}-\mathrm{Ce}-\mathrm{Na}_{2} \mathrm{WO}_{4} / \mathrm{SiO}_{2}$ gel catalyst, we implemented the same membrane electrode assembly in the tubular design (Fig. 1 bottom). A distinctive characteristic of the tubular geometry is that, along the methane flow pathway, source of oxygen is introduced into the reaction chamber by SOFC in a distributive manner and consumed instantaneously as it interacts with methane and catalyst without further accumulation. On the contrary, oxygen gas and methane are supplied all at once in a conventional fixed bed reactor or the button cell reactor (Fig. 1 top), where, as a result, the deep oxidation of hydrocarbons to oxides becomes problematic due to the local excess amount of oxygen at the entrance of the reaction zone. Cell operating current was varied in order to investigate the catalytic performance in a wide range of methane conversion. The typical reaction product distribution for a tubular reactor under different operating current is provided in the Table S2 in the supporting information. With increasing conversion of methane, the selectivity of hydrocarbon decreases. Fig. 4 shows the direct comparison of OCM performance between the button and tubular geometries at $800{ }^{\circ} \mathrm{C}$. To account for the different reactor dimensions and catalyst loading amount, the feed rate of dilute methane was adjusted to maintain the same space velocity of GHSV $=6050 \mathrm{ml} \cdot \mathrm{g}^{-1} \cdot \mathrm{h}^{-1}$ in both geometries. 


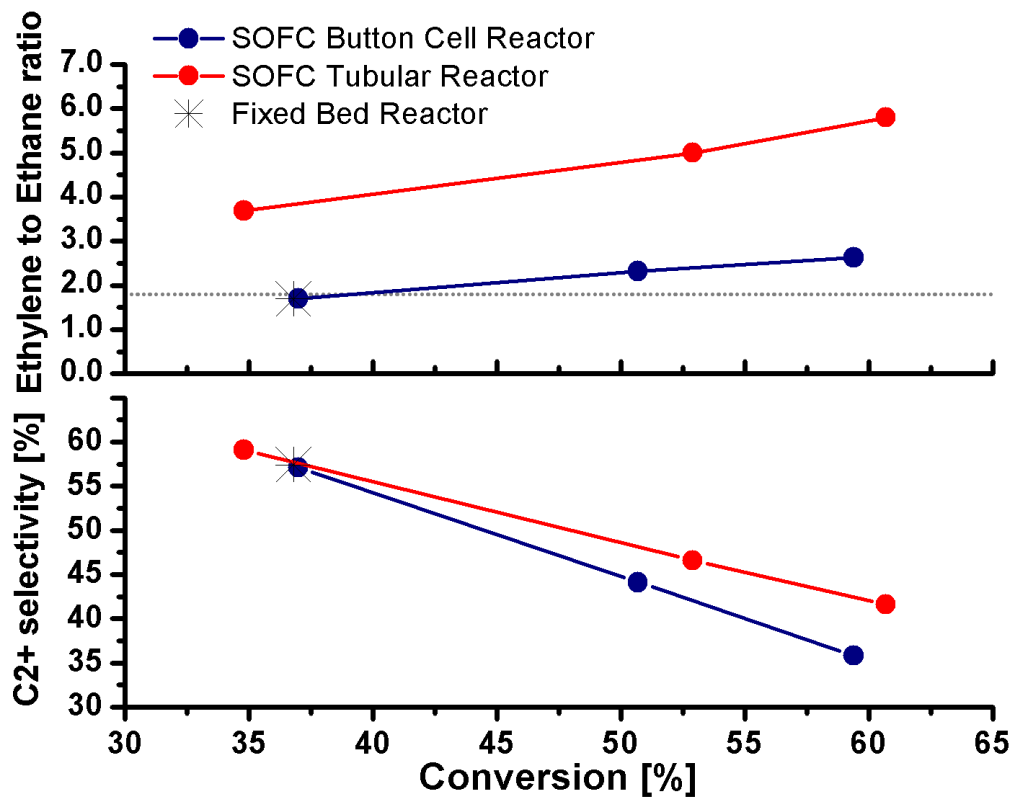

Fig. 4. Performance comparison between SOFC-OCM button cell reactor, SOFC-OCM tubular membrane reactor, and fixed bed reactor: Top, Ethylene-to-ethane ratio. Bottom, Total C2+ selectivity, including ethylene, ethane and higher hydrocarbon products.

As evident in Fig. 4, the tubular membrane reactor outperforms the button cell geometry at all conditions explored, featuring greater economic advantages with both better conversion-selectivity profile and higher ethylene-to-ethane ratio. The benefit is more pronounced at higher methane conversions, where the feed of oxygen is higher, consequently more likely to suffer from deep oxidation. With the advantage of the tubular membrane design, even though the total supply of oxygen is the same, the dilution effect by distributing oxygen ion over the entire interior of the tubular membrane effectively reduces the local oxygen concentration at each contact point along the methane pass, lowering the tendency of deep oxidation and shifting the product selectivity towards hydrocarbons. In addition, decent ethylene-to-ethane ratios are observed in the tubular reactor, over 2-fold increase from those in the button-cell reactor (Fig. 4 top) or the conventional fixed-bed reactor.[28] Besides, the ethylene-to-ethane ratio also rises with increasing methane conversion (increasing oxygen-to-methane ratio), in consistency with literature report.[38] The ethane-to-ethylene conversion can occur via two diverse routes, the oxidative and non-oxidative dehydrogenation.[34] The strong dependence of ethylene-to-ethane ratio on the oxygen-to-methane ratio suggests the oxy-dehydrogenation pathway. As a result, the tubular membrane reactor with a continuous oxygen supply along the reaction path enables an effective oxy-dehydrogenation of ethane to ethylene in the entire reaction zone, benefiting a higher ethylene-to-ethane ratio. Hence, the inherent characteristics of the tubular membrane reactor not only improves the $\mathrm{C} 2+$ selectivity by suppressing deep oxidation, but also boosts the ethylene-toethane ratio by supplying continuous oxygen source along the reaction zone. All combined, a remarkable ethylene yield, one of the most crucial indicators determining the economic merit of a given OCM process, can be achieved. In particular, with the dual benefits of the tubular membrane reactor, a 
methane conversion of $60.7 \%$ with $41.6 \%$ C2+ selectivity, 5.8 ethylene-to-ethane ratio and $19.4 \%$ ethylene yield is successfully demonstrated, highlighting the best performance among OCM reactions.

\section{Conclusions}

We have demonstrated an SOFC-OCM tubular membrane reactor design with the use of an optimized $\mathrm{Mn}-\mathrm{Ce}-\mathrm{Na}_{2} \mathrm{WO}_{4} / \mathrm{SiO}_{2}$ catalyst. OCM reaction carried out using the tubular membrane reactor establishes both superb hydrocarbon selectivity and outstanding ethylene-to-ethane ratio over the conventional fixed-bed OCM and the SOFC-OCM in the button cell design. A remarkable performance of $60.7 \%$ methane conversion with $41.6 \%$ C2+ selectivity, 5.8 ethylene-to-ethane ratio and $19.4 \%$ ethylene yield is successfully achieved using the SOFC-OCM tubular membrane reactor. The use of an oxygen-selective SOFC membrane eases the cost and safety concerns of conventional fixed bed OCM reactions by eliminating the requirement of an expensive air separation unit as well as preventing the direct co-feed of explosive methane-oxygen mixture. Moreover, comparing with the mixed ionic electronic conductor (MIEC) reactor which generally provides limited oxygen flux, the tubular SOFC reactor design offers the flexibility of precisely controlled oxygen delivery and tunable product distribution. We believe our work presents encouraging results to overcome the hurdles associated with conventional OCM processes.

\section{Acknowledgements}

This work was supported by the Science and Technology Department of Petrochina under Project NO. 2014A-2211-01. Y.T. also thanks the U. S. Department of Energy Small Business Innovation Research 2016 Phase I award DE-SC0015202 for support.

\section{References}

[1] E. McFarland, Unconventional chemistry for unconventional natural gas, Science. 338 (2012) 341-342. doi:10.1126/science.1226840.

[2] X. Guo, G. Fang, G. Li, H. Ma, H. Fan, L. Yu, C. Ma, X. Wu, D. Deng, M. Wei, D. Tan, R. Si, S. Zhang, J. Li, L. Sun, Z. Tang, X. Pan, X. Bao, Direct, nonoxidative conversion of methane to ethylene, aromatics, and hydrogen., Science. 344 (2014) 616-619. doi:10.1126/science.1253150.

[3] S.H. Morejudo, R. Zanon, S. Escolastico, I. Yuste-Tirados, H. Malerod-Fjeld, P.K. Vestre, W.G. Coors, A. Martinez, T. Norby, J.M. Serra, C. Kjolseth, Direct conversion of methane to aromatics in a catalytic co-ionic membrane reactor, Science. 353 (2016) 563-566. doi:10.1126/science.aag0274.

[4] M.Baerns and W. Hinsen, in: Proc. 8th Int. Congr. Catal., Berlin, 1984: p. 581.

[5] T. Ito, J.H. Lunsford, Synthesis of ethylene and ethane by partial oxidation of methane over lithium-doped magnesium oxide, Nature. 314 (1985) 721-722. doi:10.1038/314721b0.

[6] T. Ito, J. Wang, C.H. Lin, J.H. Lunsford, Oxidative dimerization of methane over a lithiumpromoted magnesium oxide catalyst, J. Am. Chem. Soc. 107 (1985) 5062-5068. doi:10.1021/ja00304a008. 
[7] H. Zanthoff, M. Baerns, Oxidative coupling of methane in the gas phase. Kinetic simulation and experimental verification, Ind. Eng. Chem. Res. 29 (1990) 2-10. doi:10.1021/ie00097a001.

[8] K. Otsuka, Q. Liu, M. Hatano, A. Morikawa, THE CATALYSTS ACTIVE AND SELECTIVE IN OXIDATIVE COUPLING OF METHANE. ALKALI-DOPED SAMARIUM OXIDES, Chem. Lett. 15 (1986) 467-468. doi:10.1246/cl.1986.467.

[9] K. Otsuka, K. Jinno, A. Morikawa, THE CATALYSTS ACTIVE AND SELECTIVE IN OXIDATIVE COUPLING OF METHANE, Chem. Lett. 14 (1985) 499-500. doi:10.1246/cl.1985.499.

[10] G.E. Keller, M.M. Bhasin, Synthesis of ethylene via oxidative coupling of methane. I. Determination of active catalysts, J. Catal. 73 (1982) 9-19. doi:10.1016/0021-9517(82)90075-6.

[11] M. Baerns, W. Hinsen, Chem Ztg. 107 (1983) 223-226.

[12] J.H. Lunsford, The Catalytic Oxidative Coupling of Methane, Angew. Chemie Int. Ed. English. 34 (1995) 970-980. doi:10.1002/anie.199509701.

[13] J.H. Lunsford, Catalytic conversion of methane to more useful chemicals and fuels : a challenge for the 21st century, Catal. Today. 63 (2000) 165-174.

[14] Q. Zhu, S.L. Wegener, C. Xie, O. Uche, M. Neurock, T.J. Marks, Sulfur as a selective "soft" oxidant for catalytic methane conversion probed by experiment and theory., Nat. Chem. 5 (2013) 104-9. doi:10.1038/nchem.1527.

[15] I. V. Yentekakis, C.G. Vayenas, Chemical Cogeneration in Solid Electrolyte Cells, J. Electrochem. Soc. 136 (1989) 996. doi:10.1149/1.2096899.

[16] C. Vayenas, S. Neophytides, Non-faradaic electrochemical modification of catalytic activity III. The case of methanol oxidation on Pt, J. Catal. 127 (1991) 645-664. doi:10.1016/00219517(91)90189-B.

[17] J.N. Michaels, C. Vayenas, Styrene Production from Ethylbenzene on Platinum in a Zirconia Electrochemical Reactor, J. Electrochem. Soc. 131 (1984) 2544. doi:10.1149/1.2115356.

[18] J.G. Sanchez Marcano, T.T. Tsotsis, Catalytic Membranes and Membrane Reactors, Wiley-VCH Verlag GmbH \& Co. KGaA, Weinheim, FRG, 2002. doi:10.1002/3527601988.

[19] G. Saracco, H.W.J.P. Neomagus, G.F. Versteeg, W.P.M. Van Swaaij, High-temperature membrane reactors: Potential and problems, Chem. Eng. Sci. 54 (1999) 1997-2017. doi:10.1016/S00092509(99)00009-3.

[20] K.K. Sirkar, P. V Shanbhag, a S. Kovvali, Membrane in a Reactor: A Functional Perspective, Ind. Eng. Chem. Res. 38 (1999) 3715-3737. doi:10.1021/ie990069j.

[21] B.L. Farrell, S. Linic, Oxidative coupling of methane over mixed oxide catalysts designed for solid oxide membrane reactors, Catal. Sci. Technol. 6 (2016) 4370-4376. doi:10.1039/C5CY01622C.

[22] K. Khammona, S. Assabumrungrat, W. Wiyaratn, Reviews on coupling of methane over catalysts for application in C2 hydrocarbon production, J. Eng. Appl. Sci. 7 (2012) 447-455. doi:10.3923/jeasci.2012.447.455. 
[23] K. Khammona, W. Wiyaratn, W. Appamana, S. Assabumrungrat, Oxidative coupling of methane over YSZ support catalysts for application in $\mathrm{C}<\mathrm{inf}>2</ \mathrm{inf}>$ hydrocarbon production, Eng. J. 19 (2015) 1-12. doi:10.4186/ej.2015.19.4.1.

[24] K. Otsuka, K. Suga, I. Yamanaka, Oxidative coupling of methane applying a solid oxide fuel cell system, Catal. Today. 6 (1990) 587-592. doi:10.1016/0920-5861(90)85055-S.

[25] J. Da, X. Ding, S. Shen, Investigation of the catalytic performance of $\mathrm{MgO} / \mathrm{BaCO} 3$ catalyst for the oxidative coupling of methane, Appl. Catal. A Gen. 116 (1994) 81-94. doi:10.1016/0926$860 \times(94) 80281-5$.

[26] R. Spinicci, P. Marini, S. De Rossi, M. Faticanti, P. Porta, Oxidative coupling of methane on LaAlO3 perovskites partially substituted with alkali or alkali-earth ions, J. Mol. Catal. A Chem. 176 (2001) 253-265. doi:10.1016/S1381-1169(01)00265-5.

[27] S.M.K. Shahri, A.N. Pour, Ce-promoted Mn/Na2WO4/SiO2 catalyst for oxidative coupling of methane at atmospheric pressure, J. Nat. Gas Chem. 19 (2010) 47-53. doi:10.1016/S10039953(09)60022-0.

[28] Z. Gholipour, A. Malekzadeh, R. Hatami, Y. Mortazavi, A. Khodadadi, Oxidative coupling of methane over ( $\mathrm{Na} 2 \mathrm{WO} 4+\mathrm{Mn}$ or $\mathrm{Ce}$ )/SiO2 catalysts: In situ measurement of electrical conductivity, J. Nat. Gas Chem. 19 (2010) 35-42. doi:10.1016/S1003-9953(09)60028-1.

[29] X.J. Chen, Q.L. Liu, K.A. Khor, S.H. Chan, High-performance (La,Sr)(Cr,Mn)O3/(Gd,Ce)O2-?? composite anode for direct oxidation of methane, J. Power Sources. 165 (2007) 34-40. doi:10.1016/j.jpowsour.2006.11.075.

[30] S. Tao, J.T.S. Irvine, A redox-stable efficient anode for solid-oxide fuel cells., Nat. Mater. 2 (2003) 320-323. doi:10.1038/nmat871.

[31] U. Zavyalova, M. Holena, R. Schlögl, M. Baerns, Statistical analysis of past catalytic data on oxidative methane coupling for new insights into the composition of high-performance catalysts, ChemCatChem. 3 (2011) 1935-1947. doi:10.1002/cctc.201100186.

[32] B. Zhang, J. Wang, L. Chou, H. Song, J. Zhao, J. Yang, S. Li, Effective and stable CeO2-W-Mn/SiO2 catalyst for methane oxidation to ethylene and ethane, Stud. Surf. Sci. Catal. 167 (2007) 237-242. doi:10.1016/S0167-2991(07)80138-8.

[33] O. Czuprat, T. Schiestel, H. Voss, J. Caro, Oxidative Coupling of Methane in a BCFZ Perovskite Hollow Fiber Membrane Reactor, Ind. Eng. Chem. Res. 49 (2010) 10230-10236. doi:10.1021/ie100282g.

[34] B.L. Farrell, V.O. Igenegbai, S. Linic, A Viewpoint on Direct Methane Conversion to Ethane and Ethylene Using Oxidative Coupling on Solid Catalysts, ACS Catal. 6 (2016) 4340-4346. doi:10.1021/acscatal.6b01087.

[35] J.E. ten Elshof, H.J.M. Bouwmeester, H. Verweij, Oxidative coupling of methane in a mixedconducting perovskite membrane reactor, Appl. Catal. A Gen. 130 (1995) 195-212. doi:10.1016/0926-860X(95)00098-4.

[36] Y. Lu, A.G. Dixon, W.R. Moser, Y.H. Ma, U. Balachandran, Oxygen-permeable dense membrane 
reactor for the oxidative coupling of methane, J. Memb. Sci. 170 (2000) 27-34. doi:10.1016/S0376-7388(99)00354-3.

[37] N. Lapeña-Rey, P. Middleton, The selective oxidation of methane to ethane and ethylene in a solid oxide electrolyte reactor, Appl. Catal. A Gen. 240 (2003) 207-222. doi:10.1016/S0926$860 \times(02) 00432-5$.

[38] H.R. Godini, A. Gili, O. Görke, U. Simon, K. Hou, G. Wozny, Performance analysis of a porous packed bed membrane reactor for oxidative coupling of methane: Structural and operational characteristics, Energy and Fuels. 28 (2014) 877-890. doi:10.1021/ef402041b. 